\title{
ASSESSMENT OF A LOW-COST SIDE-SCAN SONAR FOR RIVER ESTUARY UNDERWATER IMAGING
}

\section{PENGKAJIAN SIDE-SCAN SONAR BERBIAYA RENDAH UNTUK PEMETAAN BAWAH AIR MUARA SUNGAI}

\author{
Hendra Kurnia Febriawan ${ }^{1}$ * \\ ${ }^{1}$ Laboratory for Marine Survey Technology, Agency for Assessment and Application of \\ Technology (BPPT), Jakarta, 10340, Indonesia \\ *E-mail : henz.febriawan@gmail.com
}

\begin{abstract}
River and estuary areas commonly exhibit complex and heterogeneous habitats. Thus, revealing the distribution of riverbed morphologies could promote the area management and habitats protection. Since the remote sensing method and manual survey are limited to use, side-scan sonar performs an expectant outcome in underwater habitat imaging. In shallow water and stream areas, low-cost side-scan sonar imaging has become a notable subject of study, yet its use in Indonesia is still limited. This study describes an investigation of the use of a recreational-grade side-scan sonar for stream underwater imaging. A visual inspection and interpretation were implemented using a free-cost sonar software. The result shows some underwater objects and debris could be portrayed perfectly and this indicates that the inexpensive sonar system is appropriate to be used in shallow water and stream areas with a non-rough sea surface. It is suggested that this system could provide a satisfactory product to the users who do not require high accuracy and high resolution of riverbed imagery.
\end{abstract}

Keywords: estuary, river, underwater mapping, acoustic remote sensing, low-cost, side-scan sonar.

\section{ABSTRAK}

[Pengkajian Side-Scan Sonar Berbiaya Rendah untuk Pemetaan Bawah Air Muara Sungai] Area sungai dan muara pada umumnya memiliki habitat yang kompleks dan heterogen. Untuk itu, pengungkapan distribusi morfologi dasar sungai dapat mendorong pengelolaan kawasan dan perlindungan habitat di area tersebut. Dikarenakan metode penginderaan jauh dan survei manual memiliki keterbatasan, side-scan sonar dapat menampilkan hasil yang dapat diandalkan dalam pemetaan habitat bawah air. Di area perairan dangkal dan sungai, pemetaan side-scan sonar menggunakan alat yang berbiaya rendah telah menjadi topik penelitian yang penting, walaupun penggunaannya di Indonesia masih terbatas. Penelitian ini menggambarkan investigasi penggunakan side-scan sonar tipe rekreasi untuk pemetaan bawah air di area muara sungai. Inspeksi dan interpretasi visual dilakukan menggunakan perangkat lunak yang didapatkan secara bebas. Hasil penelitian menunjukkan bahwa beberapa objek bawah air dan juga debris dapat dipetakan dengan baik dan ini juga mengindikasikan bahwa sistem sonar yang berbiaya rendah tersebut sesuai untuk digunakan pada perairan dangkal seperti muara sungai dengan permukaan air yang tenang. Disarankan juga bahwa sistem tersebut dapat menghasilkan produk pemetaan bawah air yang dapat meyakinkan pengguna yang tidak terlalu membutuhkan hasil dengan akurasi dan resolusi yang tinggi.

Kata Kunci: muara, sungai, pemetaan bawah air, penginderaan jauh, akustik, murah, side-scan sonar 


\section{INTRODUCTION}

Divergent and various habitats exist in the estuary and streams areas. Buscombe (2017), Kaeser et al. (2013), and Hasan et al. (2012) asserted that mapping the spatial distribution of riverbed substrates and morphologies is essential to support the ecosystem-based management and protection of these areas since these areas are vulnerable to the damage due to natural and human activities. However, both in-situ survey and satellite remote sensing technique are time and cost consuming due to the complexity of this area and natural barriers such as reachability of the location and water column remote sensing signal penetration (Kaeser et al., 2013). Additionally, Kaeser \& Litts (2010) also added that although LiDAR which is an active remote sensing system can provide a dense and accurate elevation and depth for the shallow water, this system has a limitation in canopy cover. Thus, this system is ineffective in river areas.

Conversely, underwater acoustic-based remote sensing technologies provide a sufficient outcome in the underwater mapping of stream areas. Echosounder (multibeam and singlebeam) and side-scan sonar are two of the most popular of those technologies. Although multibeam echosounder can cover a wide area and provide accurate depth information, side-scan sonar offers a better spatial resolution to less than $10 \mathrm{~cm}$ (Diaz et $a l .$, 2004). Thus, side-scan sonar is more suitable to portray and provide high-resolution underwater imagery. Buscombe (2017) asserted that side-scan sonar allows a good result to map the fluvial and estuarine areas; to quantify the bottom substrates and morphologies; and to map underwater structures such as cables, pipelines, and wrecks. Though its use is defied due to the complexity condition of river areas (Buscombe et al., 2014).

Albeit the survey-grade of side-scan sonar has been used many years in broad sectors from industry to scientific purposes, it has some challenges. First, the industrygrade sonar system is expensive and costs around up to $\sim \$ 20,000$. Secondly, this system commonly uses a towing transducer (tow-fish) during the survey and to record the data. Thus, it is not convenient for shallow water and complex areas such as river and estuarine due to the potential crash to the underwater hazards (Kaeser et al., 2013; Cummings, 2015).

On the other hand, recreational-grade of side-scan sonar has started to become an alternative solution in alluvial underwater mapping. Initially, recreational-grade of sonar products such as Humminbird, Lowrance, and Garmin were used only for fishing purposes since it can portray a better fish schools coverage in the water column and near-bed than the fish finder. However, its use then more extensive to more scientific purposes such as morphological mapping and underwater structures monitoring. This sonar system has more flexible capabilities than the industrial-grade version. First of all, the recreational-grade sonar system is affordable. To illustrate, one unit of Humminbird Side Imaging (SI) system only costs ranging from $\sim \$ 500$ to $\$ 2,000$. Additionally, its transducer can be side mounted using a pole which makes the survey operation becomes more trouble-free. It also offers adequate results and has been used in several studies (Kaeser et al., 2013; Kaeser \& Litts, 2010; Cummings, 2015). Other research also shows that this low-cost sonar system can provide an acceptable outcome. For instance, Parnum et al. (2017) used Humminbird sonar system in a wreck survey in the Swan River (Western Australia) and seabed geomorphological mapping in the Sunshine Coast, Queensland. Greene et al. (2018) also used this sonar system in the study of seagrass monitoring in the shallow water area. In addition, free-cost sonar viewer 
software such as HumViewer also offers a promising solution to initial inspect and interpret the sonar data.

Although the study and assessment of the low-cost side-scan sonar system have been carried out worldwide, there is limited such research in Indonesia's river and estuary areas. For that reasons, this study tries to investigate the capabilities of a Humminbird Side Imaging (SI) Sonar for underwater imaging and mapping in one of Indonesia's stream areas. In addition, the HumViewer software was explored to view and reply the sonar data and inspect the underwater objects. The underwater imaging could reveal both natural phenomena (e.g., substrates and debris) and man-made structures (e.g., wrecks and structures). Thus, it is expected that the low-cost side-scan sonar can be an efficient alternative for underwater imaging and mapping, particularly related to the river stream areas in Indonesia.

\section{METHOD}

\subsection{Study Area}

The study area is Glagah estuary river located in Kulon Progo District, Yogyakarta Province, Indonesia and covering an area of about approximately $56,000 \mathrm{~m}^{2}$ from $7^{\circ} 54.5^{\prime \prime} \mathrm{S}$ to $7^{\circ} 54.9^{\prime \prime} \mathrm{S}$ and $110^{\circ} 05.018^{\prime \prime} \mathrm{E}$ to $110^{\circ} 05.049 " \mathrm{E}$ (Figure 1). The study area encompasses both natural process and man-made structures. The estuary river characterizes with shallow water ranging from $3 \mathrm{~m}$ to less than $1 \mathrm{~m}$. As peculiarize of other common estuary areas, the end of the river shows very shallow water consists of sediments accumulation from the river which is accumulated back due to the big waves of the ocean. Thus, this location could not be passed by the survey boat. In addition, the existing local fishing port consists of the jetty, riverbanks, and transportation facilities such as bridge resulting the river as an ideal case for sonar study.

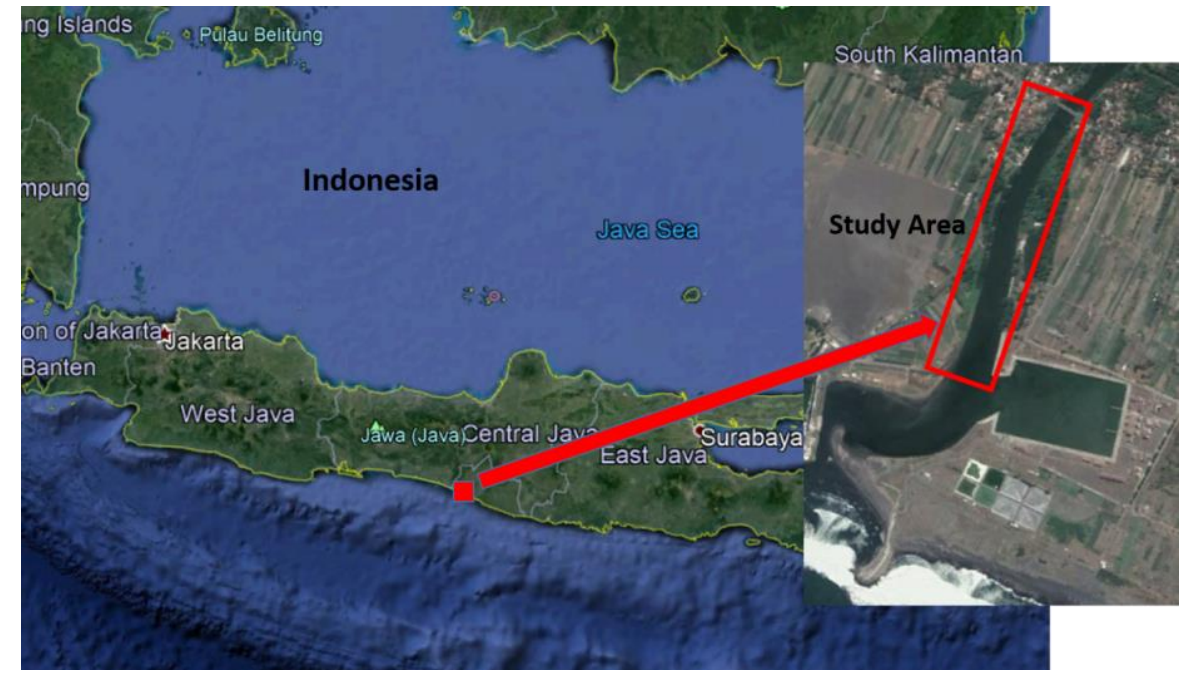

Figure 1. Map showing study area at Glagah River estuary, Kulon Progo.

\subsection{Humminbird Side Imaging (SI) Sonar}

This study used the Humminbird Helix 7 CHIRP SI G2N to record the sonar data. According to Kaeser \& Litts (2013), the Humminbird Helix 7 CHIRP SI sonar has two options of underwater imaging: side imaging and down imaging. The Side Imaging option allows users to get an accurate broad coverage of seabed imaging in two different 
side (port and starboard) and could reach a total range of 60 meters side to side (illustrated in blue in Figure 2). In addition, the Down Imaging offers a conform coverage below the transducer and produce a 2D profile of seabed (depicted in yellow and magenta in Figure 2). This option can reach a maximum depth of 30 meters below the transducer.
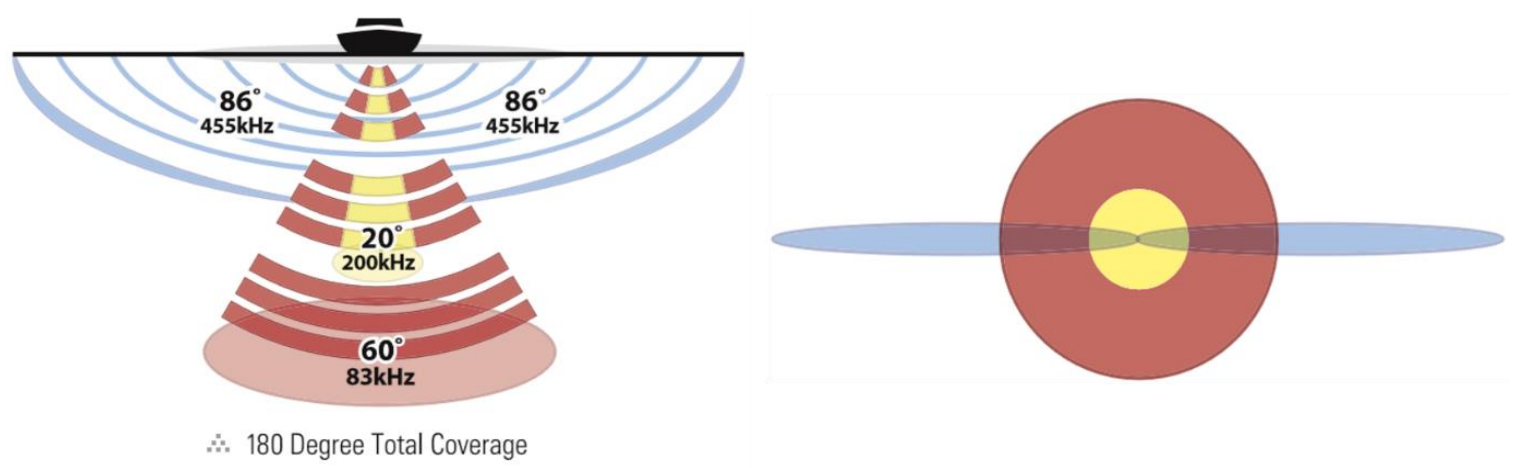

Figure 2. Diagram of beam patterns in Humminbird SI (taken from: Humminbird (2016)).

Parnum et al. (2017) asserted that there are two frequency options for SideImaging operation (455 or $800 \mathrm{kHz}$ ). However, it seems that the built-in transducer of Helix 7 only uses the $455 \mathrm{kHz}$ of frequency. Although the $800 \mathrm{kHz}$ can provide a sharper signal return and resulting in the more vivid image, the $455 \mathrm{kHz}$ is adequate to be used in common applications. Kaeser \& Litts (2013) also explained that the $455 \mathrm{kHz}$ of frequency could produce sonar imagery with $6 \mathrm{~cm}$ of pixel resolution. This resolution is adequate in detecting and depicting underwater substrates and debris.

To avoid errors of the vertical and horizontal position of the transducer, Parnum et al. (2017) suggested mounting the transducer with the same place of GNSS antenna using a pole. This technique is suitable to be used in rivers or near-shore areas, which haveshallow water and minimum effect of the vessel's movement due to wave influence. However, in some cases in using this sonar in deep water and require clearer object imagery, it requires the transducer positioned as close as possible with the seabed. Thus, in order to minimize the image distortion as an effect of the vessel's movement, the transducer can be mounted on a tow-fish with an extended cable which similar to industrial-grade of side-scan sonar. This technique was also shown in (Parnum et al., 2017).

\subsection{Positioning System}

Although the Humminbird Helix 7 SI provides an internal GPS receiver, an external GPS receiver was used to avoid the sensor offset on the boat. A Furuno GP32 GPS receiver was used to provide the position during the survey. This GPS receiver offers a capability to track not only the GPS satellites but also the WAAS satellites as the positioning correction (DGPS). In addition, this unit also provides an option to receive the DGPS beacon correction to increase the accuracy. The position and navigation data can be outputted in NMEA 0183 format consisting of two standard formats of GGA and GLL, which are suitable to be inputted to the Humminbird sonar receiver. An additional cable was required to connect the GPS receiver to the Humminbird sonar receiver. An example of this was shown by Africa et al. (2013) who 
utilized this GPS receiver in their study regarding white sharks occurrence at Gansbaai, South Africa using shark stall from diving boats. In their study, the Furuno GP32 was used to determine the anchoring position to monitor the sharks.

\subsection{Data Acquisition}

Equipment trial and data acquisition were conducted in January 2019 at high tide in the afternoon to avoid the grounded of the vessel due to shallow water and tide. A 5meter local fishing boat was used during the survey. This boat has a low draft approximately $0.5 \mathrm{~m}$ below the water surface and suitable to be used in the shallow water and river area. The Humminbird transducer was installed on the right side of the boat by mounting it using a galvanized pole. The transducer was positioned 0.5 meters below the water surface to avoid the signal obstruction from the boat hull. In addition, the Furuno GPS antenna was also installed on the same pipe of the transducer on approximately 3 meters above the water surface. This GPS receiver transmits latitude and longitude positions in standard NMEA format through its data cable. An additional connector cable of Humminbird receiver was provided to allow this GPS data can be transmitted to the receiver. Hummingbird allows a straightforward solution in using an external GPS receiver showed by no complicated settings inside the software menu. It leads to the auto-detection of the position inside the Humminbird. This was resulting in the imagery produced by the sonar does not contain sensor offset error. Moreover, a Lowrance fish-finder was used during the survey to verify the depth information of the Humminbird receiver. However, the depth data of the fish-finder was not recorded due to the limitation of the connector cable. The sensors installation diagram and field photograph can be seen in the Figure 3.

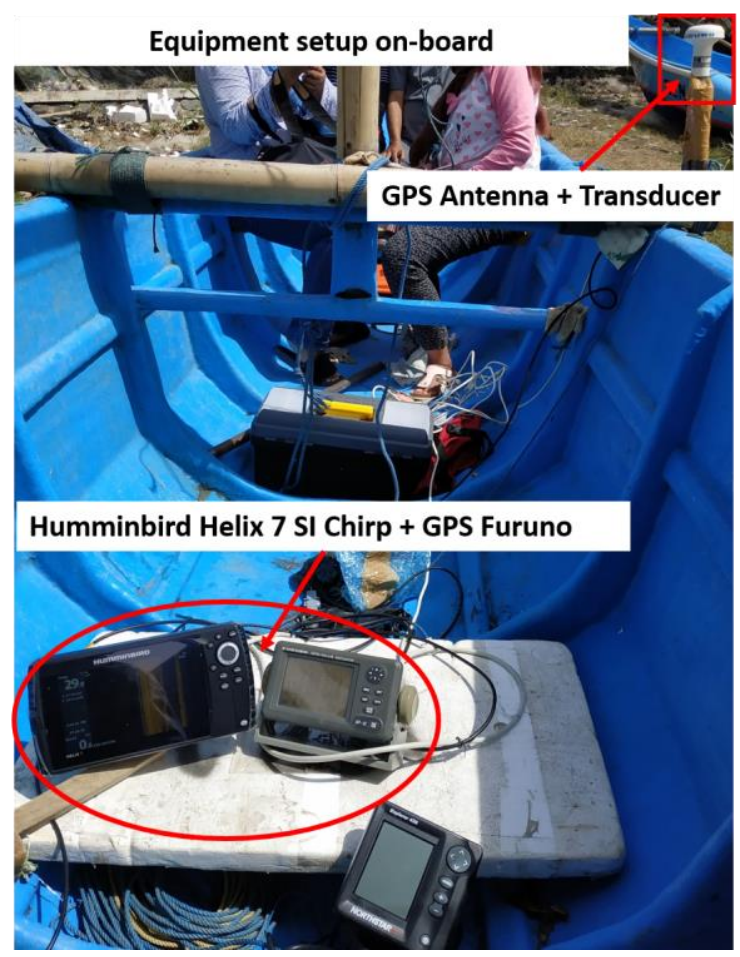

Figure 3. Equipment installation on board. 
The Humminbird sonar has two options to capture the imagery: screen snapshot and sonar recording. The study used a snapshot approach can be found in (Kaeser \& Litts, 2013), although their study explained both methods. However, the recording option was chosen during the survey, and the Humminbird unit recorded the data continuously using a micro SD storage card. This method was also used by (Hamill, Buscombe, \& Wheaton, 2018) in their study of river substrate mapping. In addition, visual examination of the Humminbird recording screen was also conducted during the survey. The photos of some essential structures which have extended objects in (e.g., pipeline, jetty, concrete riverbanks) were captured using a portable camera. These photos then were compared with sonar image snapshots that contain these underwater structures.

The continuous recording of sonar data during the survey allows more flexible post-processing methods either reply-back the recording files and screenshot some important information or using a post-processing software both industrial-standard version (e.g., SonarWiz, CARIS HIPS SIPS) and low-cost version (e.g., HumViewer, SonarTrx). Although the industrial-standard software offer more extensive tools and more advanced capabilities in processing the sonar data (such as standard workflow of side-scan sonar data processing and combination with other sensor data such as multibeamechosounder), the low-cost version is adequate enough to process the raw data, creating the mosaic, and plot the mosaic into common GIS software which can be analyzed further. After data acquisition, the sonar files were downloaded from the micro SD which then was replied and analyzed.

\subsection{Image Viewer and Interpretation}

The HumViewer software was used to reply and view the sonar files recorded on the Humminbird sonar. This software can be freely downloaded from its official website (http://humviewer.cm-johansen.dk/). This software offers several options to reply the sonar data, to change the color display of the sonar and to take some screenshots of important figures in the study area. Additionally, it allows the users to quantify the length and estimate the height of the objects based on its shadow. Although this software does not allow users to create a geo-referencing mosaic, it is adequate to preliminary inspect and interpret the sonar image without an accurate result. For example, Arney et al. (2017) used this software and has successfully assessed the mobilization of adolescent fish in the artificial reef. Since the assessment of further analysis of sonar data is not the concern of this paper and the geo-referenced mosaic is not necessary, the snapshot images of important underwater objects were captured using the HumViewer software.

Sonar imagery portrays underwater objects in amplitude (backscatter) differences. This amplitude represents the strength of the reflected acoustic pulse. This returning pulse then converted into differences in pixel tone (grey scale color level) on the image. It is affected by several factors such as density of the object, surface and substrates type that reflects the pulse, and grazing angle. 


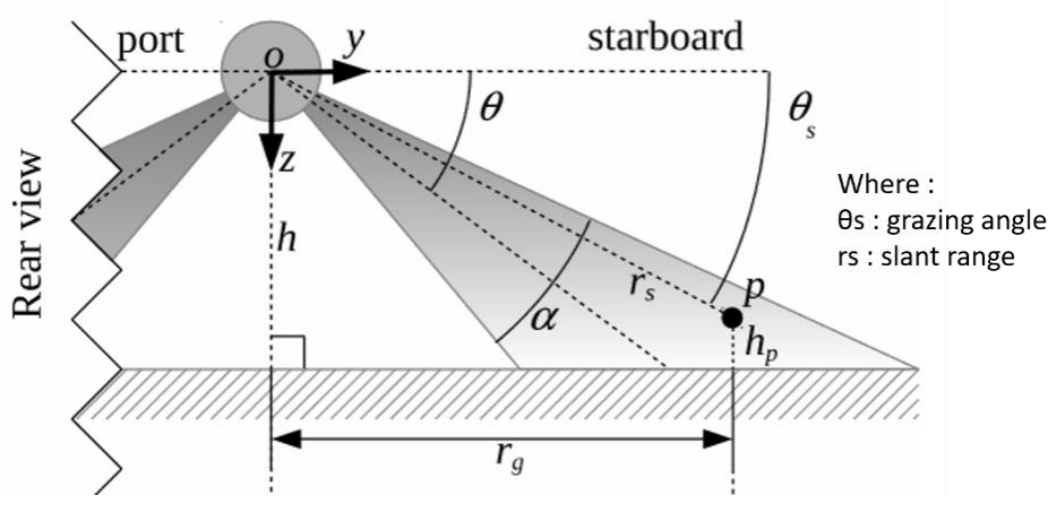

Figure 4. Illustration of acoustic signal transmission from the transducer (taken from: Burguera \& Oliver (2016)).

Kaeser \& Litts (2013) explained that the grazing angle could influence the amplitude in sonar imagery. This angle represents the angle at which the signal hits an object or surface (incidence angle). Figure 4 can be used as the illustration, Burguera \& Oliver (2016) explained that the object $\mathrm{P}$ on the seafloor could be portrayed in the image as a function of grazing angle $(\theta)$ and slant range $(r s)$. A further object which directly facing the transducer and has longer slant range would be portrayed brighter than a closer object which facing an opposite direction to the transducer. In addition, the same substrate composition will give different influence in the image. The edge of the sandbar which facing the transducer will reflect more acoustic energy than the downslope of the sandbar resulting in the brighter tone on the image. The deficiency of ground-truth data in this study leads to the uncertainty of the sediment substrates in that area. Thus, the tone difference is not related to the substrates composition. Kaeser \& Litts (2013) also added that some degree of uncertainty exists in the interpretation of sonar imagery. Thus, ground-truth data are prominent for verification. For instance, Kaeser \& Litts (2008) suggested that the ground-truth data would be useful to verify the wood estimation in the sonar imagery in their study regarding deadhead logs assessment.

Moreover, dense and hard objects such as wreck, rock boulders, or concrete bridge abutments tend to reflect more sonar energy and depicted with brighter color in the image. The soft substrates such as clay will give the darker tone in the image. Conversely, hard substrates such as boulder rocks will be portrayed in a brighter tone in the image. Additionally, flat surface will be depicted in a darker tone, and ripple surface tends to have a brighter tone at the peak of the ripple and darker at the backside of the ripple.

\section{RESULT AND DISCUSSION}

\subsection{Sonar Files}

The Humminbird SI sonar has an ability to record the sonar data in *.SON, *.IDX and *.DAT format. Parnum et al. (2017) explained that *.SON files contain the 8-bit of sonar data and *.IDX files indicate the indices of successive pings in corresponding to the SON file. They also stated that *.DAT files comprise basic information about the sonar such as time, position and sonar setting. Since the HumViewer only can view and 
reply the sonar files so this software only can read the sonar files in *.DAT format. There are other software (e.g., SonarTrx and ReefMaster) which have the capability to process the sonar data in *.SON format and allow a more advanced stage such as mosaicking and geo-referencing of sonar image.

\subsection{Image Interpretation}

The Humminbird SI imagery has similarity with common side-scan sonar imagery. It exhibits some unique appearances such as non-linear distortion of the image and noise on the image due to unstable transducer movement. In this regards, the use of a tow-fish to mount the Humminbird's transducer has more superiority to stabilize the image than the side-mounted method since stabilization of tow-fish movement in the water. However, this technique is much more risky to be used in shallow water and river areas which have a fluctuate and unpredictable seabed. The Humminbird sonar imagery depicts a coverage of 30 meters per side of the transducer. The Humminbird SI system cannot give depth across the sonar swath and only record the vertical depth below the transducer (nadir). Thus, extracting the depth and creating bathymetry from the sonar is not possible. It is also stated in the International Hydrographic Bureau (2008) that sidescan sonar is not recommended to measure the depth and is more to specify the preliminary survey areas that need to be detailed afterward. In regards to image interpretation in relation to the Humminbird SI and HumViewer, this study presents several predominant findings during the survey.

\subsubsection{Underwater Bridge Supports}

Initially, the Humminbird SI was operated at surrounding of bridge abutments and underwater pipeline in two adjacent directions. The screenshot of those objects portrayed on the image can be seen in the Figure 5.

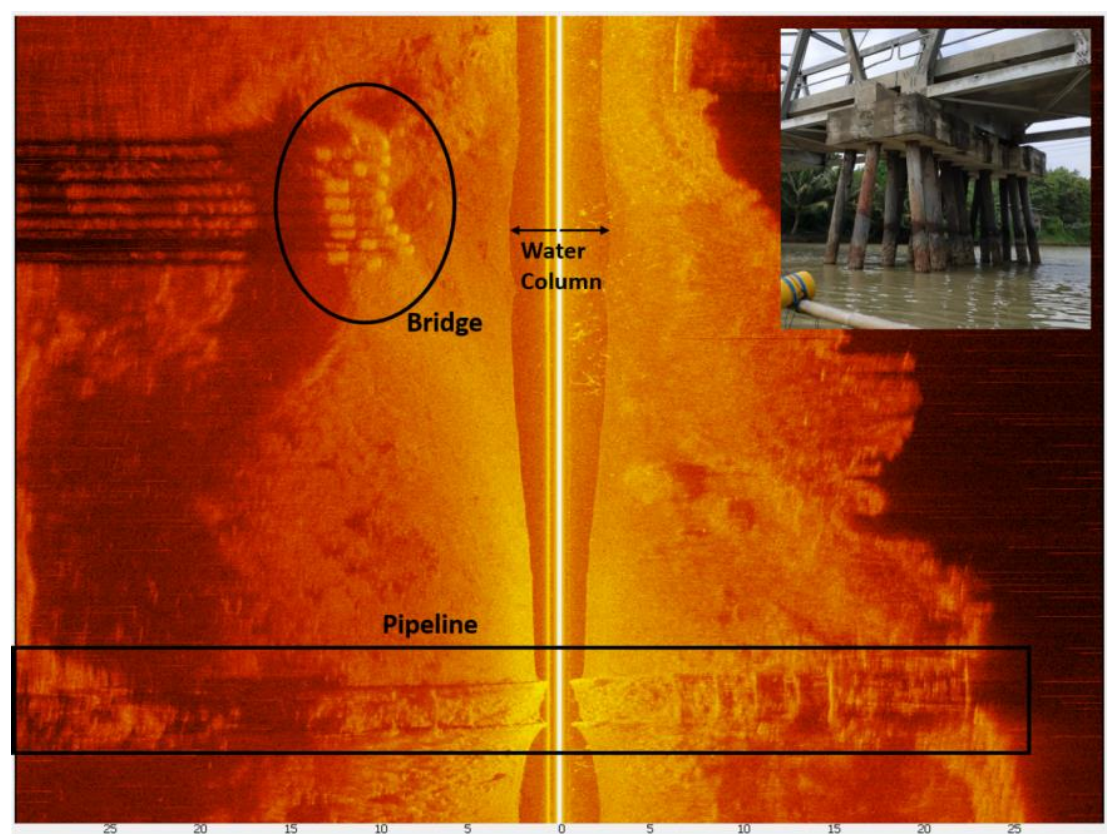

Figure 5. Underwater bridge supports and pipeline in the study area. 
In order to interpret the sonar image, Kaeser \& Litts (2013) suggests using the bright and dark parts. Shadows could represent the height of the object with a taller object will be depicted as a longer shadow. In addition, fish could also be portrayed as shadows and these shadows could show their position (distance) from the seabed. In addition to shadow, shades could also explain the seabed covers. A close and dense terrain such as sediment, rocks, and step ascending terrain would be portrayed as bright shades. Conversely, the soft returns (sand or mud) or descending terrain would be depicted as dark shades.

Figure 5 shows that the shadows behind the bridge structures indicate that these objects have a high dimension and reaching the water surface. This structure consists of approximately 20 concrete abutments with a total dimension of 9.2 meters in length and 3.9 meters in width. The riverbank also depicts a narrower length near the bridge which represents the bridge's concrete structure from its natural riverbanks. There are some rip-rap around the abutments as a remnantof its construction previously. Figure 5 also depicts an underwater pipeline crossing the river. This pipeline has 2.4 meters of diameter and consists of two parallel structures with its buffers. The two parallel structures are separated 4 meters each other. Additionally in the sonar image, water column represents important information that needs to be considered in interpreting the image. Kaeser \& Litts (2013) asserts that water column depicts the relative depth of the water beneath the vessel nadir. Thus, in the transducer-mounted operation with a relatively flat-water surface (e.g., river), the variations of water column width illustrate the variations of the seabed terrain when the boat passes over. It is noticed from the figure 5 that the water-column above the pipeline and the bridgechanges and decreasing from $1 \mathrm{~m}$ to $3 \mathrm{~m}$ below the water surface. Presumably, the area of the pipeline has a lower depth, and it goes deeper toward the bridge structures.

It also can be seen that the seabed between the bridge abutments and the pipeline shows a non-flat surface depicted by a contrast tone from the bright surface to sharply darker. It can be assumed that the darker area has a lower surface than the bright area which blocked the acoustic signal from the transducer. This surface difference causes a different grazing angle. On the other hand, this fluctuate area are possibly caused by sediment changes due to river current. Although the ground-truth data of riverbed substrates are not available in this study, it is predicted that this area consists of clay or sand which showed by the dark-medium bright of tone in the image.

Side-scan sonar also could provide a promising result for bridge inspection and monitoring, as can be seen in the Figure 5 that depicts a bridge structure. Traditionally, bridge inspection employs certified divers to provide underwater photographs and a detailed report including maintenance recommendation of the bridge. However, it leads to some hazards and dangerous situations for the divers such as strong currents, limited visibility, unpredictability debris, and dangerous marine wildlife. Thus, the underwater acoustic technique can tackle those limitations. For instance, Laurent (2017) utilized side-scan sonar to investigate the bed conditions and existing scour near the bridge. Although it is not possible to quantify the bathymetry or scour near the structure since it only provides a two-dimensional map without vertical/height information.

\subsubsection{Jetty Supports, Debris, and Riverbank}

The second trial was trying to capture a fishing jetty and some debris at surroundings. It can be seen that during the survey, the vessel was passing around 12 meters left side of the riverbank. The left side of the transducer shows a darker tone 
from 10 meters of distance upwards. It is presumably due to the close distance of the transducer and seabed resulting the further seabed (objects) cannot be portrayed clearly.

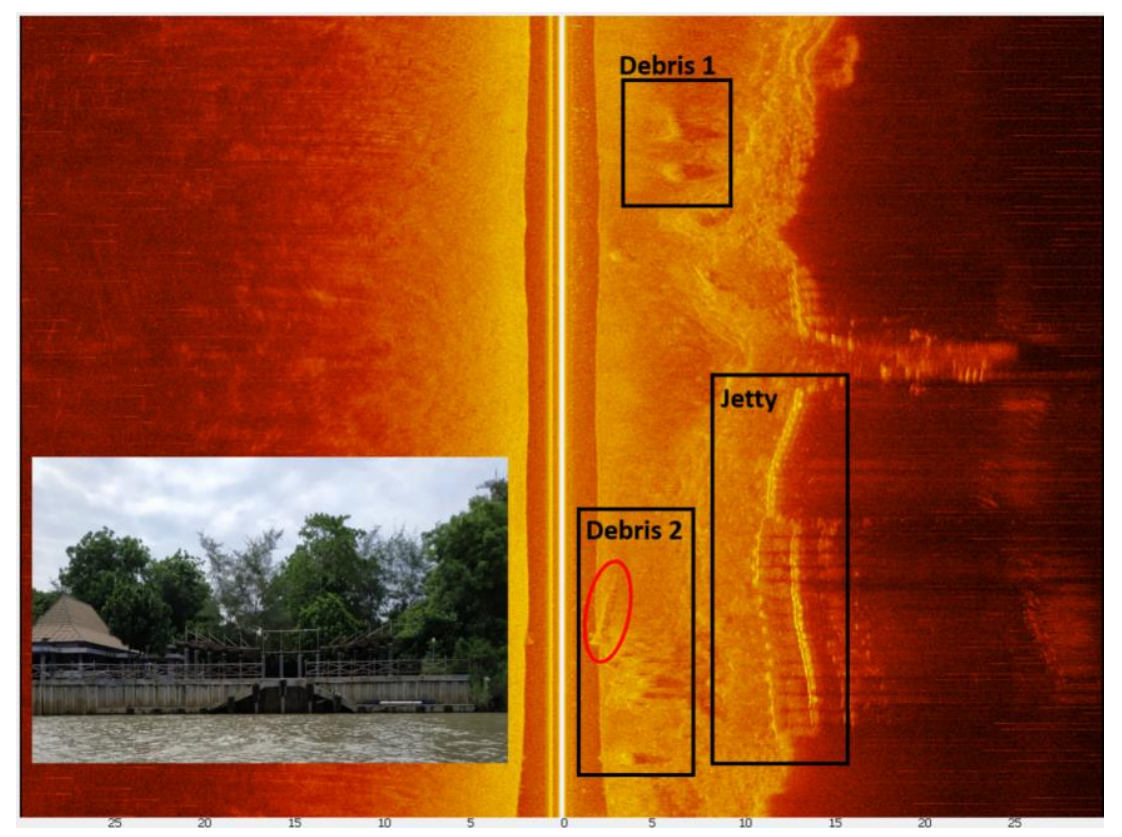

Figure 6. Jetty supports and debris in the study area.

The Humminbird sonar also captured a fishing jetty (Figure 6). It is noticed in the Figure 6, the jetty's supports consist of two parallel abutments. Although its structure longwise straightly, it is portrayed as a bending structure in the image. This is due to the vessel's movement when it crossed the structure. The HumViewer software depicts the jetty has approximately 50 meters of length. Two debris in the first rectangle (Figure 6) show a height of 0.5 meters and 0.4 meters from the bed respectively (calculated from its shadow). Twelve meters of an unidentified object (shown inside rectangle 2) was also captured and lies almost 1 meter from the seabed. However, this object does not have shadow since it is located below the nadir (depicted in the water column). Thus, the measurement of its height was conducted using the scale bar.

The riverbank and some debris were also portrayed as the third instance (Figure 7). It can be seen that the riverbank, which consists of dense concrete material without any underwater space, is portrayed as a continuous straight line with a bright tone. This bright tone is due to the strong signal of the sonar that reflected from this hard concrete material (effect of grazing angle) as the boat passed 15 meters from the wall. The riverbed at the location is relatively flat and shallow (identified with the short water column around 1.5 meters below the transducer). This shallow depth caused the acoustic signal to only cover a short distance on both sides of the transducer. As a result, the riverbed in the left side and outside 10 meters of the transducer is portrayed in the darker tone. This is possibly due to obstruction of the signal since the transducer was mounted in the right side of the boat. In addition, two debris were identified in the image near the nadir. This debris has a height of 0.5 meters and 0.1 meters from the riverbed respectively. 


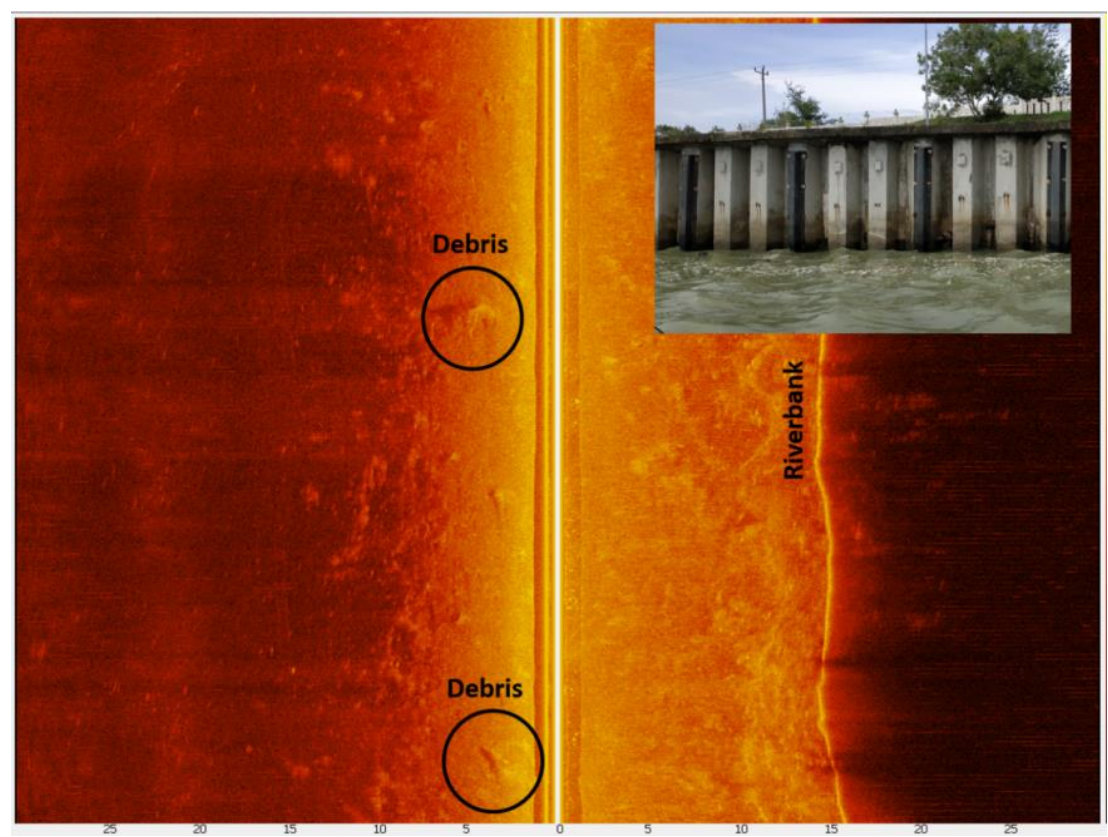

Figure 7. Riverbank and debris in the study area.

\subsection{Future Directions}

Some lookout research opportunity of the low-cost side-scan sonar is widely opened. The use of more advanced processing software such as SonarTrx can lead to a more preferable outcome. This software provides some functions to process the sonar files, create geo-referenced mosaics and generate maps which can be exported further into some GIS software such as Global Mapper and ESRI ArcGIS. Furthermore, textural features which can be derived from that sonar mosaics also can be another promising topic. The Grey Level Co-occurrence Matrix (GLCM), which is second-order texture features, becomes a prevalent subject in many studies of side-scan sonar image segmentation. As can be found in (Lianantonakis \& Petillot, 2007; Hamilton, 2015; Buscombe, 2017; Hamill et al., 2018) who used these textures in sonar image analysis. The combination of both first and second-order also showed a promising result in sonar image classification (Febriawan et al., 2019). Those approaches can be applied using low-cost sonar image in this study.

Moreover, the automated and computer-based segmentation and classification techniques of sonar imagery recently become a favorite subject of study. This low-cost and customized classification program allows the researchers to explore, combine, and compare different algorithms of classification. Additionally, the development of machine learning techniques can be a prominent topic in sonar imagery classification. For instance, Doherty et al. (1989) used Decision Tree (DT) in sonar classification, Rhinelander (2017) who explored sonar image classification using Support Vector Machine (SVM), and Febriawan et al., (2019) who compared both DT and SVM based classification of side-scan sonar mosaics. Other machine learning techniques such as Random Forest and Naïve Bayes also can be another option to study. Those such algorithms combination and comparison also can be another preference topic in lowcost side-scan sonar. 


\section{CONCLUSION}

This study tried to examine the use of a low-cost sonar system and a free-cost sonar viewer software for the riverbed imaging and mapping. A Humminbird Helix 7 CHIRP SI G2N was utilized along with Furuno GP32 GPS receiver to record the sonar data in a river estuary. A continuous record method was carried out to conduct a sonar post-processing stage. Additionally, a visual interpretation and measurement were also conducted using HumViewer software.

Some primary results were presented: Underwater Bridge Supports, Jetty Supports, Debris and Riverbank. Results show that sonar imagery portrays the underwater objects such as bridge abutments, jetty supports, and riverbank very clearly. The riverbed topography also can be depicted vividly with bright and dark tone showing the fluctuation of the bed. The HumViewer software also shows a promising capability to inspect the sonar. This software can identify the underwater structures and debris and measure its dimension. In addition, the height of the objects also can be obtained. Although the accuracy of the measurement is unknown, it can be used for preliminary investigation. It is suggested that the more credible result could be achieved with more adequate processing software. However, this study has proven that a combination of a recreational-grade side-scan sonar and free-cost sonar software can provide a promising result for underwater imaging and mapping in the shallow water and stream areas.

\section{REFERENCES}

Africa, S., Towner, A. V, Underhill, L. G., Jewell, O. J. D., \& Smale, M. J. (2013). Environmental influences on the abundance and sexual composition of white sharks Carcharodon carcharias in Gansbaai, South Africa. PLOS ONE, 8(8), 1-11. https://doi.org/10.1371/journal.pone.0071197.

Arney, R. N., Froehlich, C. Y. M., \& Kline, R. J. (2017). Recruitment patterns of juvenile fish at an artificial reef area in the Gulf of Mexico. Marine and Coastal Fisheries, 9(1), 79-92. https://doi.org/10.1080/19425120.2016.1265031.

Burguera, A., \& Oliver, G. (2016). High-resolution underwater mapping using side-scan sonar. PLoS ONE, 11(1), 1-41. https://doi.org/10.1371/journal.pone.0146396.

Buscombe, D, Grams, P. E., \& Kaplinski, M. A. (2014). Characterizing riverbed sediment using high-frequency acoustics : 1 . Spectral properties of scattering. Journal of Geophysical Research: Earth Surface, 2674-2691. https://doi.org/10.1002/2014JF003189.Received.

Buscombe, Daniel. (2017). Shallow water benthic imaging and substrate characterization using recreational-grade sidescan-sonar. Environmental Modelling and Software, 89, 1-18. https://doi.org/10.1016/j.envsoft.2016.12.003.

Cummings, G. A. (2015). Habitat Suitability and Availability for Rainbow Trout Oncorhynchus Mykiss in the Canyon Reservoir Tailrace and Evaluation of Side Scan Sonar for Habitat Mapping in a Semi-wadable River. M.S. thesis, Texas State University.

Diaz, R. J., Solan, M., \& Valente, R. M. (2004). A review of approaches for classifying benthic habitats and evaluating habitat quality. Journal of Environmental Management, 73, 165-181. https://doi.org/10.1016/j.jenvman.2004.06.004.

Doherty, M. F., Landowski, J. G., Maynard, P. F., Uber, G. T., Fries, D. W., \& Maltz, F. H. (1989). Side scan sonar object classification algorithms. In Proceedings of the 6th International Symposium on Unmanned Untethered Submersible Technology 
(pp. 417-424). Durham, NH, USA, USA: IEEE. https://doi.org/10.1109/UUST.1989.754734.

Febriawan, H. K., Helmholz, P., \& Parnum, I. M. (2019). Support Vector Machine and Decision Tree based classification of side-scan sonar mosaics using textural features. In The International Archives of the Photogrammetry, Remote Sensing and Spatial Information Sciences (Vol. XLII, pp. 10-14). https://doi.org/https://doi.org/10.5194/isprs-archives-XLII-2-W13-27-2019.

Greene, A., Rahman, A. F., Kline, R., \& Rahman, M. S. (2018). Side scan sonar: A cost-efficient alternative method for measuring seagrass cover in shallow environments. Estuarine, Coastal and Shelf Science, 207, 250-258. https://doi.org/10.1016/j.ecss.2018.04.017.

Hamill, D., Buscombe, D., \& Wheaton, J. M. (2018). Alluvial substrate mapping by automated texture segmentation of recreational-grade side scan sonar imagery. PLoS ONE, 13(3). https://doi.org/10.1371/journal.pone.0194373.

Hamilton, L. J. (2017). Towards autonomous characterisation of side scan sonar imagery for seabed type by unmanned underwater vehicles. In Proceedings of Acoustics 2017 (pp. 1-10). Perth, Australia.

Hasan, R. C., Ierodiaconou, D., \& Monk, J. (2012). Evaluation of four supervised learning methods for benthic habitat mapping using backscatter from multi-beam sonar. Remote Sensing, 4(11), 3427-3443. https://doi.org/10.3390/rs4113427.

Humminbird. (2016). HELIX G2 and HELIX G2N series operations manual.

International Hydrographic Bureau. (2008). IHO standards for hydrographic surveys, 5 th edition, SP no.44.

Kaeser, A. J., \& Litts, T. L. (2008). An assessment of deadhead Logs and large woody debris using side scan sonar and field surveys in streams of Southwest Georgia. Fisheries, 33(12), 589-597. https://doi.org/10.1577/1548-8446-33.12.589.

Kaeser, A. J., \& Litts, T. L. (2010). A novel technique for mapping habitat in navigable streams using low-cost side scan sonar. Fisheries, 35(4), 163-174. https://doi.org/10.1577/1548-8446-35.4.163.

Kaeser, A. J., \& Litts, T. L. (2013). An illustrated guide to low-cost, side scan sonar habitat mapping. TXAFS- San Marcos.

Kaeser, A. J., Litts, T. L., \& Tracy, T. W. (2013). Using low-cost side-scan sonar for benthic mapping throughout the lower Flint River, Georgia, USA. River And Research Applications, 644(January 2012), 634-644. https://doi.org/10.1002/rra.

Laurent, W. K. (2017). Field study of scour critical bridges in Rhode Island. M.Sc. Thesis, University Of Rhode Island.

Lianantonakis, M., \& Petillot, Y. R. (2007). Sidescan sonar segmentation using texture descriptors and active contours. In IEEE Journal of Oceanic Engineering (Vol. 32, pp. 744-752). IEEE. https://doi.org/10.1109/JOE.2007.893683.

Parnum, I. M., Ellement, T., Perry, M. A., Parsons, M. J. G., \& Tecchiato, S. (2017). Using recreational echo-sounders for marine science studies. In Proceedings of Acoustics 2017 (pp. 1-10). Perth, Australia.

Rhinelander, J. (2017). Feature Extraction and Target Classification of Side-Scan Sonar Images. In 2016 IEEE Symposium Series on Computational Intelligence (SSCI). Athens, Greece. https://doi.org/10.1109/SSCI.2016.7850074. 